\title{
Bushen-Qiangdu-Zhilv decoction inhibits osteogenic differentiation of rat fibroblasts by regulating connexin 43
}

\author{
YING-YAN ZHOU ${ }^{1}$, RUN-YUE HUANG ${ }^{2}$, JIE-HUA LIN ${ }^{1}$, YONG-YUE XU ${ }^{1}$, XIAO-HONG HE ${ }^{2}$ and YI-TING HE $^{3}$ \\ ${ }^{1}$ Department of Rheumatology, College of Guangzhou University of Chinese Medicine, Guangzhou, Guangdong 510006; \\ ${ }^{2}$ Department of Rheumatology, The Second Affiliated Hospital, Guangzhou University of Chinese Medicine, \\ Guangzhou, Guangdong 510006; ${ }^{3}$ Department of New Drug Development, The Second Affiliated Hospital, \\ Guangzhou University of Chinese Medicine, Guangzhou, Guangdong 510120, P.R. China
}

Received June 16, 2015; Accepted March 7, 2016

DOI: $10.3892 /$ etm.2016.3292

\begin{abstract}
Bushen-Qiangdu-Zhilv (BQZ) decoction is a traditional Chinese medicinal compound widely used for treating ankylosing spondylitis (AS). However, the mechanisms underlying effects of BQZ remain largely unknown. Osteoblast differentiation of fibroblasts plays an important role in heterotopic ossification $(\mathrm{HO})$ of $\mathrm{AS}$, and connexin 43 (Cx43) is crucially involved in the osteoblast differentiation of fibroblasts. The aim of the present study was to evaluate the effects of BQZ on the osteogenic differentiation of fibroblasts by regulating $\mathrm{Cx} 43$. Rat fibroblasts were treated with freeze-dried powder of $\mathrm{BQZ}$, in the presence or absence of recombinant human bone morphogenetic protein-2 (rhBMP-2). MTS assays were performed to examine the inhibitory effects of BQZ on fibroblast proliferation. Western blot assays were conducted to detect the protein expression of core-binding factor alpha 1 (Cbf $\alpha 1), C x 43$ and phosphorylated Cx43 (pCx43). BQZ appeared to inhibit fibroblast proliferation in a dose-dependent manner. Furthermore, the expression of $\mathrm{Cbf} \alpha 1$ and $\mathrm{Cx} 43 / \mathrm{pCx} 43$ was significantly suppressed by BQZ, with or without rhBMP-2 stimulation. Therefore, the present results
\end{abstract}

Correspondence to: Professor Yi-Ting He, Department of New Drug Development, The Second Affiliated Hospital, Guangzhou University of Chinese Medicine, 111 Dade Road, Guangzhou, Guangdong 510120, P.R. China

E-mail: yitinghe@126.com

Abbreviations: BQZ, Bushen-Qiangdu-Zhilv decoction; AS, ankylosing spondylitis; HO, heterotopic ossification; Cx43, Connexin43; rhBMP-2, recombinant human bone morphogenetic protein-2; Cbfo1, core binding factor alpha1; $\mathrm{pCx} 43$, phosphorylated Connexin43; BMPs, bone morphogenetic proteins; NSAIDs, nonsteroidal anti-inflammatory drugs; TNF, anti-tumor necrosis factors; PBS, phosphate-buffered saline; DMEM, Dulbecco's modified Eagle's medium; FBS, fetal bovine serum; GJ, gap junction

Key words: ankylosing spondylitis, osteogenic differentiation, connexin 43 , fibroblasts indicate that BQZ may exert an anti-AS effect by suppressing the osteogenic differentiation of fibroblasts via $\mathrm{Cx} 43$ regulation.

\section{Introduction}

Ankylosing spondylitis (AS) is a chronic inflammatory disease characterized by syndesmophytes and ankylosis (1). AS affects $\sim 0.22 \%$ of the population in China, which is similar to the prevalence of AS in Europe and America (2). Heterotopic ossification (HO), manifesting as tendon and ligament ossification, is the primary cause leading to disability in AS. Fibroblasts are the principal cell-type in ligament tissues, and are closely associated with $\mathrm{HO}$ in AS patients (3). Core-binding factor alpha $1(\mathrm{Cbf} \alpha 1)$ is the osteogenic marker gene of fibroblasts, and a prior study has suggested that $\mathrm{Cbf} \alpha 1$ expression is regulated by bone morphogenetic protein (BMP) signaling pathways (4). Among the BMPs, BMP-2 has been demonstrated to have the most marked osteogenic capacity $(5,6)$. Notably, serum levels of BMP-2 in AS patients with spinal fusion is higher than healthy controls or AS patients without spinal fusion (7). In in vitro studies, BMP-2 has been shown to induce osteogenic differentiation of fibroblasts $(5,6)$. However, following connexin 43 (Cx43) knockout, BMP-2 is unable to induce osteogenic differentiation (8). Cx43 is widely expressed in fibroblasts and serves a crucial function in the ossification and differentiation of fibroblasts (9).

At present, there is no entirely satisfactory therapeutic strategy for AS, although nonsteroidal anti-inflammatory drugs (NSAIDs) have been considered as the cornerstone treatment options $(10,11)$. However, the side effects of long-term use of NSAIDs include gastrointestinal discomfort and the risk of cardiovascular incidence (12). Biological agents, such as tumor necrosis factor (TNF) inhibitor, were developed during the first decade of 21 st century, and are typically recommended for the management of AS (13). However, TNF inhibitor agents cannot lead to the improvement of the modified stokes AS spinal cord of AS patients, since these drugs are unable to suppress new bone formation in such patients (14). Therefore, the identification of safer and more effective drugs or therapeutic strategies with the inhibitory effects on new bone formation are required. 
Traditional Chinese medicine has been applied to the treatment of rheumatic diseases for thousands years, and may provide an alternative choice for patients with AS. Bushen-Qiangdu-Zhilv (BQZ) decoction was established in Rheumatology (15). In a recent clinical study, a modified form of BQZ was demonstrated to be more effective than sulfasalazine, a typical DMARD, for treating AS by relieving clinical symptoms and inflammatory activity indicators in AS patients (15). However, the mechanisms underlying the effects of $\mathrm{BQZ}$ remain largely unclear. In a previous report, we showed that the extracts from BQZ may induce significant anti-inflammatory effects by suppressing TNF- $\alpha$ and interleukin-1 expression (16). The aim of the present study was to determine whether $\mathrm{BQZ}$ could have the effects on $\mathrm{HO}$ and new bone formation in AS.

\section{Materials and methods}

Cell lines and cell culture. Primary cells were obtained from 5 male Sprague-Dawley rats (age, 2-4 weeks). Rats were provided by the Animal Experimental Center of Guangzhou University of Chinese Medicine (Guangzhou, China). Fibroblast cell lines were established from rat ligament tissues from the hip joint. The tissues were aseptically collected and cut into small pieces. The pieces were washed several times in 0.01 M sterile phosphate-buffered saline (PBS; pH 7.4; Hyclone, Logan, UT, USA) then seeded into a $25-\mathrm{cm}^{3}$ flasks (Corning, NY, USA). Primary cell cultures were grown in Dulbecco's modified Eagle's medium (DMEM; Thermo Fisher Scientific, Inc., Waltham, MA, USA) with $20 \%$ fetal bovine serum (FBS) and $1 \%$ penicillin-streptomycin (both from Hyclone) at $37^{\circ} \mathrm{C}$ in a humidified atmosphere containing $5 \% \mathrm{CO}_{2}$. When the cells reached $80 \%$ confluence, they were digested with EDTA-trypsin (0.25\%; Thermo Fisher Scientific, Inc.,) and completed the passage with the proportion of 1:1 for the first generation. For the second and third generations, cells were passaged with the proportion of 1:2 or 1:3, and DMEM with $10 \%$ FBS were used in the sub-culture. Fibroblasts at the third passage were used in the experiments outlined below.

Preparation of the freeze-dried $B Q Z$ powder. As previous described (16), BQZ is a mixture composed of 22 species of herbal plant. All components, purchased from Kangei Pharmaceutical Co., Ltd. (Guangzhou, China), were identified by the authors Professor Yi-Ting He and Dr Xiao-Hong He. A weight of $319 \mathrm{~g}$ of BQZ was boiled in $1.4 \mathrm{~L}$ ultrapure water in a Chinese medicine decocting pot (Guangzhou Wen Xin Electronics Co. Ltd., Guangzhou, China) for $2 \mathrm{~h}$, yielding $500 \mathrm{ml}$ of solution. The solution was frozen at $-80^{\circ} \mathrm{C}$ for $24 \mathrm{~h}$, and subsequently lyophilized for $24 \mathrm{~h}$ using a freeze-dryer (Christ Alpha 2-4 LSCplus; Marin Christ Gefriertrocknungsanlagen GmbH, Osterode am Harz, Germany). Finally, the solution was freeze-dried, powdered and stored at $4^{\circ} \mathrm{C}$ in tightly sealed 25-ml centrifuge tubes (Yancheng Great Wall Glass Instruments Manufacturer Co., Ltd., Yancheng, China) sealed with parafilm. The final yield of the material was $18 \%(57.4 \mathrm{~g})$.

MTS analysis. The effect of BQZ on fibroblast proliferation was detected using a CellTiter $96{ }^{\circledR}$ AQueous One Solution Cell Proliferation Assay (Promega Corporation, Madison, WI,
USA), according to the manufacturer's instructions. Cells were seeded at a density of $105 / \mathrm{ml}$ into 96 -well plates and incubated overnight for attaching. The cells were divided into 7 groups with 5 wells for every group. BQZ with a concentration of $0 \mu \mathrm{g} / \mathrm{ml}$ (control group), $25 \mu \mathrm{g} / \mathrm{ml}, 50 \mu \mathrm{g} / \mathrm{ml}, 100 \mu \mathrm{g} / \mathrm{ml}$, $200 \mu \mathrm{g} / \mathrm{ml}, 500 \mu \mathrm{g} / \mathrm{ml}$ and $750 \mu \mathrm{g} / \mathrm{ml}$ were added into the 7 groups respectively. A total of 5 groups were set with BMP-2 treated with $0,12,24,48$ or 72 h. Following treatment with graded levels of BQZ, the control and treated cells were incubated for $48 \mathrm{~h}$. Following the addition of $20 \mu \mathrm{l}$ MTS to each micro well, the plates were read at $492 \mathrm{~nm}$ using a microplate reader (Bio-Rad Laboratories, Inc., Hercules, CA, USA). The growth inhibition rate was calculated using the formula: Inhibition rate $=\left[1-\left(\mathrm{OD}_{450 \text { treatment }} / \mathrm{OD}_{450 \text { control }}\right)\right] \times 100 \%$.

Western blot analysis. Cells were washed with ice-cold PBS, collected and homogenized with radioimmunoprecipitation assay lysis buffer (Wuhan Boster Biological Technology, Ltd., Wuhan, China) containing $1 \mathrm{X}$ PBS, $1 \%$ Nonidet P-40, $0.5 \%$ sodium deoxycholate, $0.1 \%$ SDS and $1 \mathrm{mM}$ phenylmethylsulfonyl fluoride (Beyotime Institute of Biotechnology, Beijing, China). Total protein was extracted and measured using a bovine serum albumin protein assay kit (Bio-Rad Laboratories, Inc.). Equal quantities of protein $(20 \mu \mathrm{g})$ were boiled for $10 \mathrm{~min}$, separated using a 10\% SDS-PAGE, and transferred to polyvinylidene difluoride membranes (both from EMD Millipore, Billerica, MA, USA). Subsequently, the membranes were blocked with $5 \%$ non-fat milk for $1 \mathrm{~h}$. Next, they were incubated overnight at $4^{\circ} \mathrm{C}$ with the appropriate primary antibody subsequent to washing with PBS containing $1 \%$ Tween 20 , followed by exposure to the secondary antibody at room temperature for $1 \mathrm{~h}$. The following antibodies were used for the western blot analysis: Rabbit polyclonal antibodies against polyclonal rabbit Cx43 (1:500; 3512S), polyclonal pCx43 (1:500; 3511S) and monoclonal rabbit Cbfa1 (1:500; 12556S) were obtained from Santa Cruz Biotechnology, Inc. (Santa Cruz, CA, USA). Rabbit polyclonal antibody against monoclonal rabbit GAPDH $(1: 1,000 ; 2118)$ was obtained from Cell Signaling Technology, Inc. (Beverly, MA, USA). Secondary antibody, affinity purified goat anti-rabbit (IgG H\&L), was also purchased from Cell Signaling Technology, Inc. Specific proteins were detected by using an enhanced chemiluminescence detection system (Clarity ${ }^{\mathrm{TM}}$ ECL Western Blotting Substrate; Bio-Rad Laboratories, Inc.) to the membranes. Densitometry was performed using Image Lab version 4.1 software (Bio-Rad Laboratories, Inc.).

Immunohistochemical assay. In the present study, two groups (A and $\mathrm{B}$ ) were set. The reagents, including the $3 \% \mathrm{H}_{2} \mathrm{O}_{2}$ blocking buffer, primary and secondary antibodies were from the SV0002 two-step immunohistochemical detection kit (Wuhan Boster Biological Technology, Ltd., Wuhan, China). The cells of the two groups were fixed with $4 \%$ paraformaldehyde for $10 \mathrm{~min}$. Next, the cells were incubated in $3 \% \mathrm{H}_{2} \mathrm{O}_{2}$ for $15 \mathrm{~min}$ and then in blocking buffer for $1 \mathrm{~h}$ at room temperature. Next, the primary antibody (1:250; anti-vimentin) was added to the cells of group A followed by incubation for $3 \mathrm{~h}$ at room temperature. The cells were rinsed thrice for $5 \mathrm{~min}$ each time in PBS with gentle agitation. The conjugate HRP secondary antibody was then applied to the cells of groups A and B and 


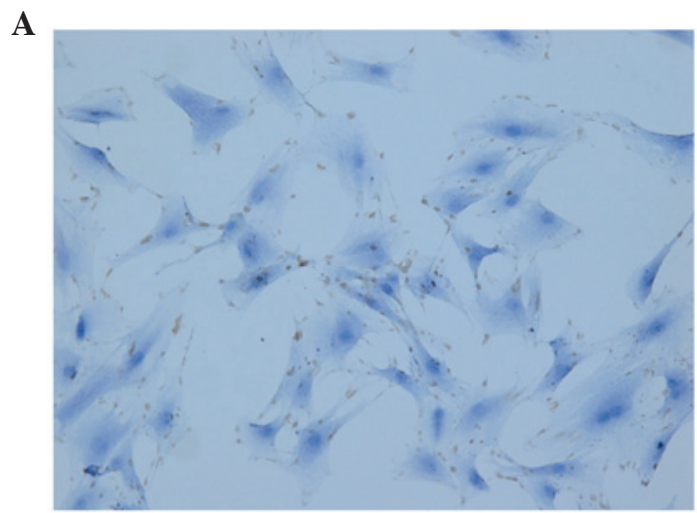

B

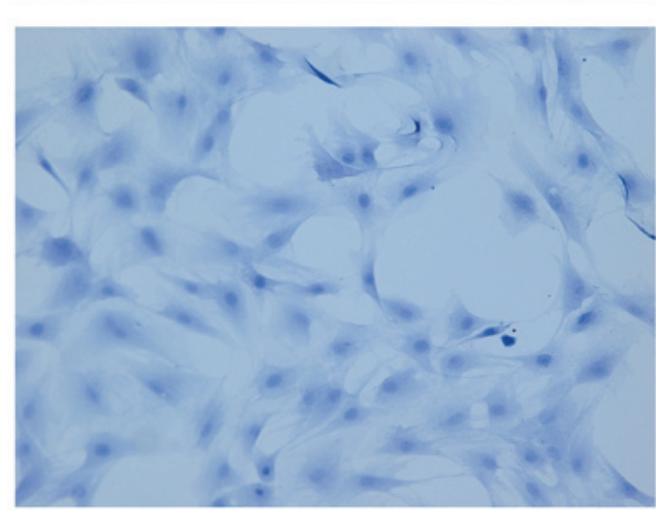

Figure 1. Cell source identification with immunohistochemistry assay. (A) Experimental group was positive for staining with anti-vimentin antibody. (B) Negative control group was negative for staining with anti-vimentin antibody. Magnification, x400.

incubated for $1 \mathrm{~h}$ at room temperature. The cells were then rinsed thrice for 2 min each time with TBS. The blot was developed with a chromogen (DBA chromogenic reagent kit; Wuhan Boster Biological Technology, Ltd.) for $10 \mathrm{~min}$ at room temperature and it was rinsed with distilled water thrice for 5 min each time. It was counterstained with hematoxylin, dehydrated, cleared and then observed with a DMI3000 inverted fluorescence microscope (Leica Microsystems GmbH, Wetzlar, Germany).

Statistical analysis. Data are presented as the mean \pm standard deviation from experiments repeated at least twice. Student's t-test was used to compare the difference between two groups. One-way analysis of variance followed by Dunnett's test was employed for comparisons among more than two groups. Statistical analyses were conducted using SPSS software, version 11.6 (SPSS, Inc., Chicago, IL, USA). A two-tailed $\mathrm{P}$-value of $<0.05$ was considered to indicate a statistically significant difference.

Ethics statement. Animal work in this study was conducted in strict accordance with the United States Institute of Animal Research guidelines for the care and use of laboratory animals (17), and was approved by the Institutional Animal Care and Use Committee, Guangzhou University of Chinese Medicine (Ethic no: 0088139; Guangzhou, China). Animals were sacrificed by decapitation under anesthesia consisting of $0.5 \mathrm{ml}$ ketamine $(100 \mathrm{mg} / \mathrm{ml}$; Shanghai Civi

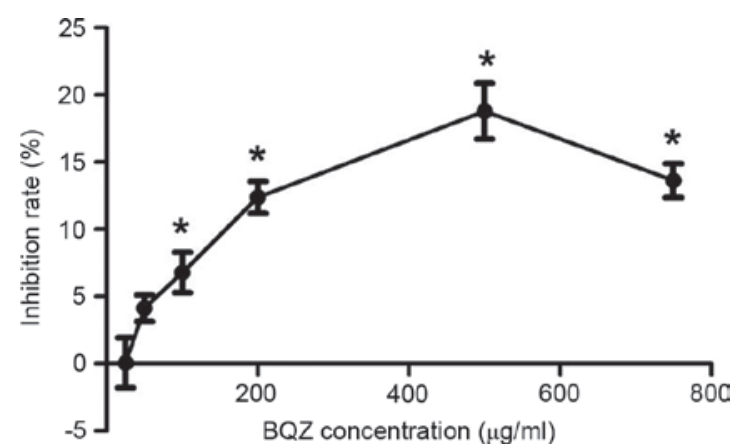

Figure 2. Inhibitory effect of BQZ on the proliferation of fibroblast cells Cells were treated with graded levels of BQZ for $48 \mathrm{~h}$. Viability of fibroblast cells was assessed using an MTS assay. Data is shown as the mean \pm standard deviation of three independent experiments ( ${ }^{*} \mathrm{P}<0.05$ vs. control group). One way analysis of variance followed by Dunnett's test was performed. BQZ, Bushen-Qiangdu-Zhilv.

Chemical Technology Co., Ltd., Shanghai, China) combined with $0.05 \mathrm{ml}$ xylazine $(20 \mathrm{mg} / \mathrm{ml}$; Shanghai Civi Chemical Technology Co., Ltd.) at a dosage of $0.55 \mathrm{ml} / 100 \mathrm{~g}$ body weight.

\section{Results}

Cellular growth, morphological character and cell source identification. In the primary culture, cells emerged from tissue pieces between days 5 and 7 . After day 8 , the fibroblasts encircled the tissue pieces and grew in a stellate pattern, forming outgrowth. After day 11, the cells thrived and grew to $\sim 50 \%$ confluence, with a small space among the tissue pieces. After day 13 the cells proliferated without any space among the pieces, but had not adhered to each other. After day 15, the cells adhered to each other. At passages, the cells grew stably, in net-like formation at a low density, in bundle-like or whorl-like formation at a high density. The cells were spindle-shaped, with a plump cell body, even cytoplasm, round nucleus and a clear nucleolus. Cells were positive for staining with a monoclonal antibody against vimentin, confirming that the cells were fibroblasts derived from the mesoderm (Fig. 1).

$B Q Z$ inhibited proliferation of fibroblast cells. The inhibitory effect of BQZ on fibroblast cells proliferation was measured by the MTS assay (Fig. 2). The mean of inhibition rate for each group was $0.07 \%(25 \mu \mathrm{g} / \mathrm{ml}), 4.13 \%(50 \mu \mathrm{g} / \mathrm{ml}), 6.79 \%$ $(100 \mu \mathrm{g} / \mathrm{ml}), 12.38 \%(200 \mu \mathrm{g} / \mathrm{ml}), 18.79 \%(500 \mu \mathrm{g} / \mathrm{ml})$ and $13.63 \%(750 \mu \mathrm{g} / \mathrm{ml})$. BQZ at concentrations of 100, 200, 500 and $750 \mu \mathrm{g} / \mathrm{ml}$ could significantly inhibit the proliferation of fibroblast cells $(\mathrm{P}<0.05)$. As BQZ at concentration of $500 \mu \mathrm{g} / \mathrm{ml}$ led to the highest inhibition rate, even higher than that of $750 \mu \mathrm{g} / \mathrm{ml}$, it was used in the high-dose group in the subsequent experiments. In addition, the concentrations of $100 \mu \mathrm{g} / \mathrm{ml}$ and $200 \mu \mathrm{g} / \mathrm{ml}$ were employed in the low-dose group and middle-dose group respectively in the next experiments.

Effect of BQZ on protein expression of Cbfal and Cx43/pCx43 in fibroblast cells without BMP-2 treatment. After treatment with different concentrations of BQZ for $48 \mathrm{~h}$, the protein expression levels of $\mathrm{Cbf} \alpha 1$ and $\mathrm{Cx} 43 / \mathrm{pCx} 43$ were detected by western blot analysis. Fig. 3A shows that BQZ could inhibit the 
A

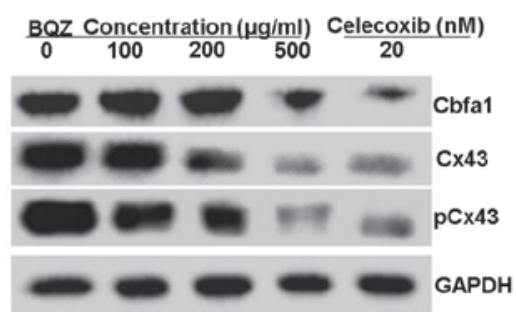

C

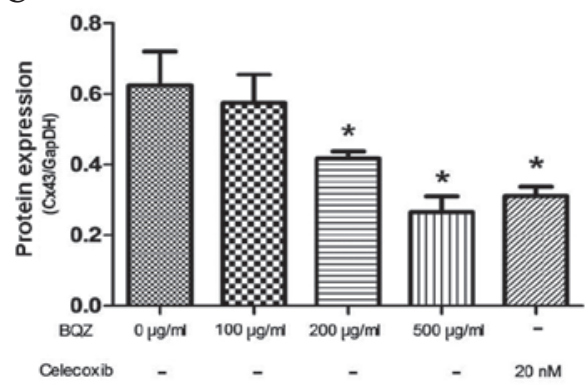

D

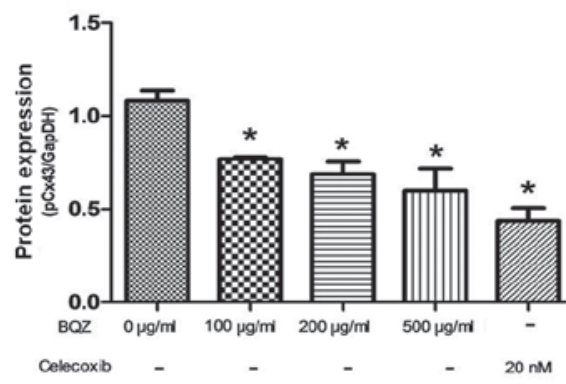

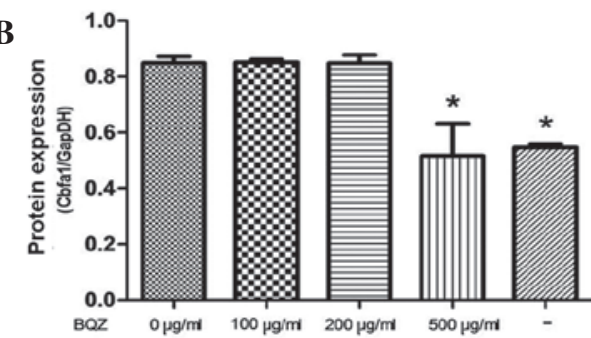

Figure 3. BQZ decreased $\mathrm{Cbf} \alpha 1$ and $\mathrm{Cx} 43 / \mathrm{pCx} 43$ protein expression in fibroblast cells. (A) BQZ dose-dependently decreased protein expression of Cbfa1 $(62 \mathrm{kDa}), \mathrm{Cx} 43(43 \mathrm{kDa})$ and pCx43 (43 kDa) in fibroblast cells. Cells in six-well plates were treated with BQZ at different concentrations for $48 \mathrm{~h}$. Cells without treatment served as controls. (A) Total extracts were subjected to western blot analysis, with GAPDH (37 kDa) used as a loading control. (B-E) Results are representative of three independent experiments, and densitometric analyses for blots were shown. (B) $500 \mu \mathrm{g} / \mathrm{ml} \mathrm{BQZ} \mathrm{and} \mathrm{celecoxib} \mathrm{treatments} \mathrm{significantly}$ decreased level of Cbf $\alpha 1$ protein. (C) Cx43 protein expression was significantly decreased with 200 and $500 \mu \mathrm{g} / \mathrm{ml} \mathrm{BQZ} \mathrm{and} \mathrm{celecoxib} \mathrm{treatment.} \mathrm{(D)} \mathrm{BQZ} \mathrm{of}$ all tested concentrations and celecoxib decreased the protein expression of pCx43 markedly. (E) BQZ had no significant effects on the ratio of Cx43/pCx43. ${ }^{\text {"P }}<0.05$ vs. cells without BQZ treatment. One way analysis of variance followed by Dunnett's test was performed. BQZ, Bushen-Qiangdu-Zhilv; Cbf $\alpha 1$, core-binding factor alpha $1 ; \mathrm{Cx} 43$, connexin 43 .

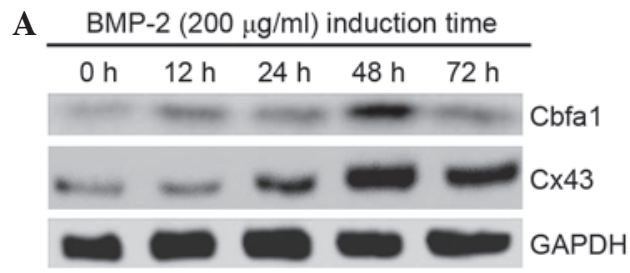

B

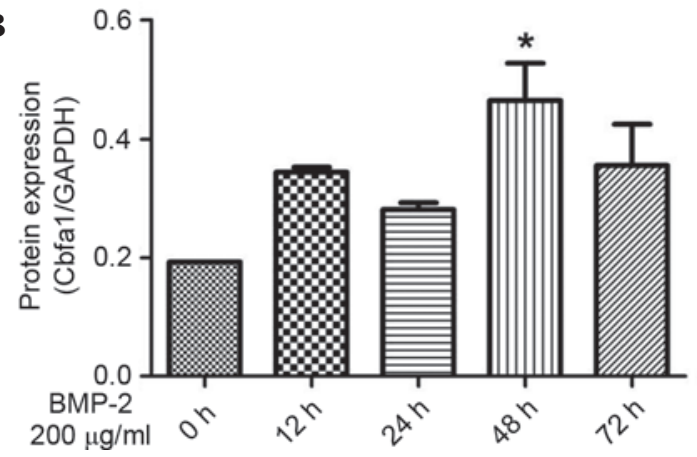

C

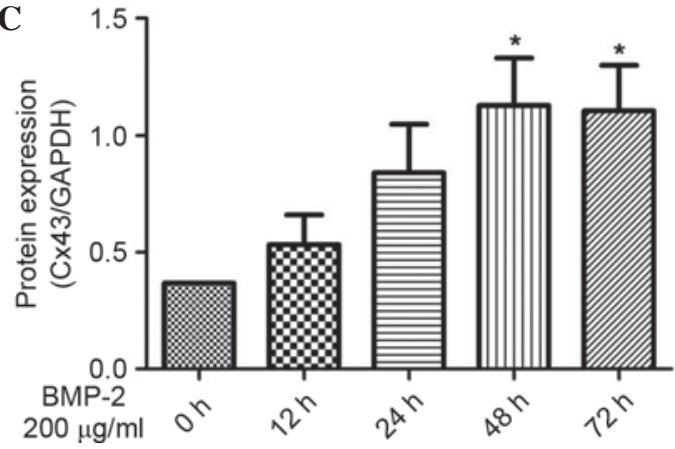

Figure 4. Recombinant human (rh)BMP-2 increased Cbf $\alpha 1$ and Cx43 protein expression in fibroblast cells. (A) BQZ increased protein expression of Cbf $\alpha 1$ $(62 \mathrm{kDa})$ and $\mathrm{Cx} 43(43 \mathrm{kDa})$ in fibroblast cells. Cells in six-well plates were treated with rhBMP-2 $(200 \mu \mathrm{g} / \mathrm{ml})$ for 12, 24, 48 and $72 \mathrm{~h}$. Cells without treatment served as controls. (A) Total extracts were subjected to western blot analysis, with GAPDH (37 kDa) used as a loading control. (B and C) Results are the representative of three independent experiments, and densitometric analyses are shown. (B) $200 \mu \mathrm{g} / \mathrm{ml} \mathrm{rhBMP}-2$ significantly increased the expression of Cbfal protein at $48 \mathrm{~h}$. (C) Cx43 protein expression was significantly increased with $200 \mu \mathrm{g} / \mathrm{ml}$ rhBMP-2 treatment for 48 and $72 \mathrm{~h}$. ${ }^{*} \mathrm{P}<0.05 \mathrm{vs}$. cells without rhBMP-2 treatment. One way analysis of variance followed by Dunnett's test was performed. BMP-2, bone morphogenetic protein 2; Cbfa1, core-binding factor alpha 1; Cx43, connexin 43 .

protein expression of Cbf $\alpha 1$ and $\mathrm{Cx} 43 / \mathrm{pCx} 43$. Fig. 3B demonstrates that, after treating the cells with $500 \mu \mathrm{g} / \mathrm{ml} \mathrm{BQZ,} \mathrm{the}$ level of Cbfa1 protein was decreased by $39.2 \%$. However, treatment with 100 and $200 \mu \mathrm{g} / \mathrm{ml} \mathrm{BQZ}$ produced a negligible effect on $\mathrm{Cbf} \alpha 1$ expression. $\mathrm{Cx} 43$ protein expression was decreased by 33.1 and $57.4 \%$ respectively after treatment with 200 and $500 \mu \mathrm{g} / \mathrm{ml} \mathrm{BQZ}$, and such effects were similar to celecoxib treatment $(\mathrm{P}>0.05)$ (Fig. 3C). Moreover, the protein expression 
A



B

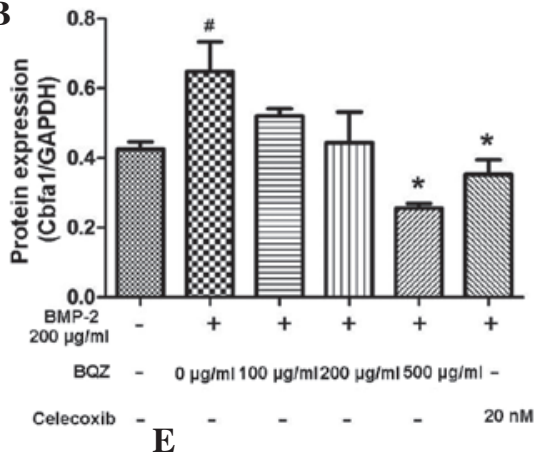

C

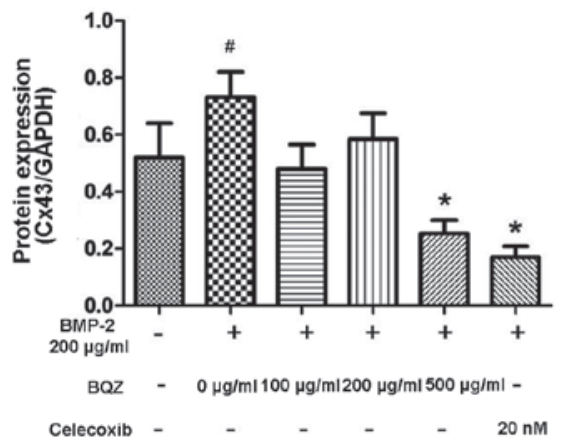

D
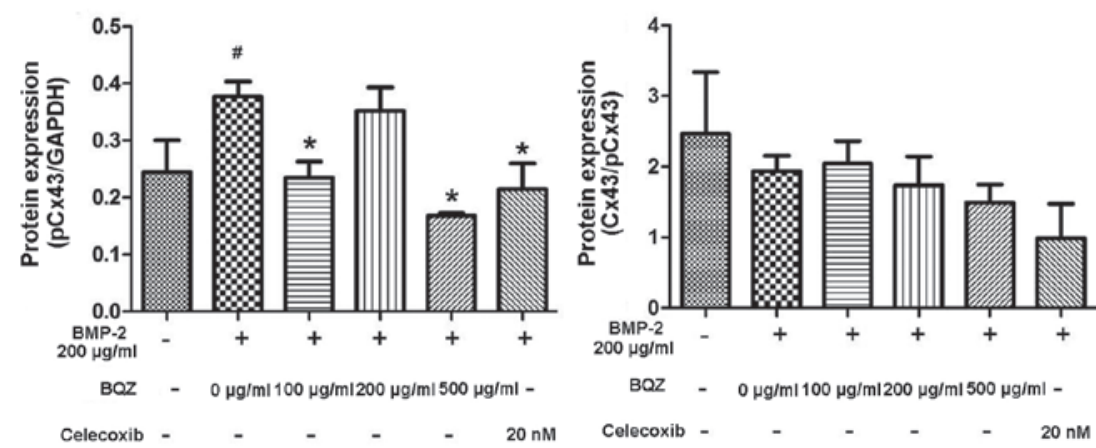

Figure 5. BQZ decreased $\mathrm{Cbf} \alpha 1$ and $\mathrm{Cx} 43 / \mathrm{pCx} 43$ protein expression in fibroblast cells in the presence of rhBMP. (A) BQZ blocked the rhBMP-2 stimulation effect on increasing the protein levels of Cbfa1 $(62 \mathrm{kDa}), \mathrm{Cx} 43(43 \mathrm{kDa})$ and pCx43 $(43 \mathrm{kDa})$. Cells in six-well plates were treated with BQZ at different concentrations for $30 \mathrm{~min}$ before stimulating with rhBMP-2 for $48 \mathrm{~h}$. Cells solely treated with rhBMP-2 served as controls. (A) Total extracts were subjected to western blot analysis, with GAPDH (37 kDa) used as a loading control. (B-E) Results are representative of three independent experiments, and densitometric analyses are shown. (B and C) $500 \mu \mathrm{g} / \mathrm{ml} \mathrm{BQZ} \mathrm{significant} \mathrm{decreased} \mathrm{the} \mathrm{Cbf} \alpha 1$ and $\mathrm{Cx} 43$ protein expression in the presence of rhBMP-2 (P<0.05). (D) The pCx43 protein expression has significantly decreased after treatment with 100 and $500 \mu \mathrm{g} / \mathrm{ml}$ BQZ in the presence of rhBMP-2 (P<0.05). (E) BQZ had no significant effects on the ratio of $\mathrm{Cx} 43 / \mathrm{pCx} 43$. No significant difference showed compared to the celecoxib group $(\mathrm{P}>0.05){ }^{*} \mathrm{P}<0.05$ vs. cells without BQZ or rhBMP-2 treatment. "P $<0.05$ vs. cells solely treated with rhBMP-2. One way analysis of variance followed by Dunnett's test was performed. BQZ, Bushen-Qiangdu-Shilv; BMP-2, bone morphogenetic protein 2; Cbfa1, core-binding factor alpha 1; Cx43, connexin 43.

of pCx43 was significantly decreased by $28.9,36.5$ and $44.6 \%$ at concentrations of 100,200 and $500 \mu \mathrm{g} / \mathrm{ml} \mathrm{BQZ}$, respectively (Fig. 3D). Celecoxib treatment served as the additional control in all groups, and showed that the inhibitory effects of $\mathrm{BQZ}$ on the protein expression of $\mathrm{Cbf} \alpha 1$ and $\mathrm{Cx} 43 / \mathrm{pCx} 43$ were similar to celecoxib treatment. Expression of $\mathrm{Cbf} \alpha 1$ and $\mathrm{Cx} 43 / \mathrm{pCx} 43$ in the $500 \mu \mathrm{g} / \mathrm{ml} \mathrm{BQZ} \mathrm{group} \mathrm{showed} \mathrm{no} \mathrm{significant} \mathrm{difference}$ compared with the celecoxib group ( $\mathrm{P}>0.05)$.

BMP-2 increased the protein expression of Cbfal and Cx43 in fibroblast cells. BMP-2 is considered to serve a crucial role in osteoblast differentiation and the subsequent bone formation by stimulating Cbfal (18), which is essential for osteoblast differentiation and bone formation (19). A previous reports demonstrated that fibroblasts could differentiate into osteogenic cells in response to BMP-2 at concentration of $200 \mu \mathrm{g} / \mathrm{ml}$ (20). Therefore, $200 \mu \mathrm{g} / \mathrm{ml} \mathrm{BMP}-2$ was utilized in the present study to construct in vitro model for new bone formation of AS patients.

Following treatment with $200 \mu \mathrm{g} / \mathrm{ml}$ recombinant human BMP-2 (rhBMP-2) for 12-72 h, the expression levels of Cbfal and $\mathrm{Cx} 43$ protein were determined using western blot experiments. As shown in Fig. 4A, Cbf $\alpha 1$ and $\mathrm{Cx} 43$ were increased with rhBMP-2 induction. The densitometric analysis of the western blots shows that $200 \mu \mathrm{g} / \mathrm{ml}$ rhBMP-2 significantly increased the expression of $\mathrm{Cbf} \alpha 1$ protein at $48 \mathrm{~h}$ by $141.1 \%$ compared with at $0 \mathrm{~h}(\mathrm{P}<0.05)$ (Fig. 4B). In addition, the expression of Cx43 protein was increased by 206.8 and $200.7 \%$ at 48 and $72 \mathrm{~h}$, respectively, with stimulation by $200 \mu \mathrm{g} / \mathrm{m}$ rhBMP-2 compared with at $0 \mathrm{~h}(\mathrm{P}<0.05)($ Fig. $4 \mathrm{C})$. Therefore, it appears that $48 \mathrm{~h}$ is an appropriate induction period for osteoblast differentiation and was used in the following experiments.

Effect of BQZ on protein expression of $C b f \alpha 1$ and $C x 43 / p C x 43$ in fibroblast cells stimulated with rhBMP-2. Following treatment with graded levels of BQZ for 30 min before $48 \mathrm{~h}$ stimulation with rhBMP-2, the expression of $\mathrm{Cbf} \alpha 1$ and $\mathrm{Cx} 43 / \mathrm{pCx} 43$ protein in fibroblasts was detected by western blot analysis. Fig. 5A shows that the protein levels of Cbf $\alpha 1, \mathrm{Cx} 43$ and pCx43 were increased by rhBMP-2 stimulation, which is in line with the data shown in Fig. 4, and that the effect was inhibited by pre-treatment of BQZ. Fig. 5B and C show that $500 \mu \mathrm{g} / \mathrm{ml} \mathrm{BQZ}$ significantly decreased the $\mathrm{Cbf} \alpha 1$ and $\mathrm{Cx} 43$ protein expression by 60.6 and $65.4 \%$ respectively, in the presence of rhBMP-2 $(\mathrm{P}<0.05)$. Furthermore, no significant difference was detected between the $500 \mu \mathrm{g} / \mathrm{ml} \mathrm{BQZ}$ group compared to the celecoxib group $(\mathrm{P}>0.05)$. $\mathrm{pCx} 43$ protein expression significantly decreased by 37.7 and $55.4 \%$ after treatment with 100 and $500 \mu \mathrm{g} / \mathrm{ml} \mathrm{BQZ}$, respectively, compared with the $0 \mu \mathrm{g} / \mathrm{ml} \mathrm{BQZ}$ group $(\mathrm{P}<0.05)$. Celecoxib treatment served as the additional control in all groups, and showed that the effects of $\mathrm{BQZ}$ were similar to those of celecoxib.

\section{Discussion}

Heterotopic ossification (HO) in connective tissue, such as ossification of tendons and ligament, is the characteristic 
pathological associated with AS (1). Fibroblasts are crucial cells in connective tissue and play an important role in the HO pathological process (3). Moreover, fibroblasts have the potential of expressing osteogenic marker genes and differentiating into osteoblasts (21). A prior study showed that osteoblasts overexpress two genes, namely $\mathrm{Cbf} \alpha 1$ and osteocalcin (OC), in comparison with fibroblasts (22). Cbfal is a key transcription factor and regulator of osteogenic differentiation, which may also regulate the expression of other osteogenic differentiation marker genes and osteogenic phenotype related genes such as alkaline phosphatase (ALP), OC, type I collagen, thereby enhancing the expression of osteogenic phenotypes to promote osteogenic differentiation and bone formation (23-25). Thus, the increased expression of $\mathrm{Cbf} \alpha 1$ protein in fibroblasts is usually considered to be a sign of the osteogenic differentiation of fibroblasts, whereas the decreased expression of Cbf $\alpha 1$ may indicate the suppression of osteogenic differentiation (20).

Cbfa1 protein expression has been demonstrated to be markedly increased in fibroblasts compared to the fibroblasts without BMP-2 induction, which are differentiated into osteogenic cells in response to BMP-2 (20). Notably, it has been reported that the expression of $\mathrm{Cbf} \alpha 1$ is regulated by the BMP signal pathway (26). The present study also confirmed that BMP-2 is able to induce the expression of Cbfa1, resulting in the osteogenic differentiation of rat fibroblasts.

Connexin 43 (Cx43), a major gap junction (GJ) protein widely expressed in fibroblasts, plays a critical role in osteogenic differentiation (8). Loss of Cx43 may result in decreased bone formation and resorption, which indicates that $\mathrm{Cx} 43$ is vital to normal bone metabolism (27). A previous study showed that Cx43 signaling pathway is involved in the osteogenic differentiation of fibroblasts (28). Alteration of the expression of the gap junction protein $\mathrm{Cx} 43$ modulates osteogenic marker gene expression (29). In addition, the cellular communication mediated by $\mathrm{Cx} 43$ is crucial for normal osteogenic differentiation induced by BMP-2 (6). The present study indicated that BMP-2 is able to induce the protein expression of $\mathrm{Cbf} \alpha 1$ in fibroblasts, in addition to increasing the protein level of $\mathrm{Cx} 43$. Therefore, $\mathrm{Cx} 43$ may be involved in the $\mathrm{HO}$ pathological change of AS by interfering with the BMP-2-Cbf $\alpha 1$ pathway.

BQZ is a widely used traditional Chinese medicinal formula with a long history of application in the treatment of AS, and is speculated to be effective in relieving clinical symptoms and signs (15). BQZ is effective not only for inflammation control, but also for ossification delay. Our previous study presented the anti-inflammatory effects of BQZ, this indicating potentially mechanisms underlying its anti-AS effects (16). In the present study, potential anti-ossifying effect of BQZ was investigated.

Firstly, BZQ was shown to inhibit the proliferation of rat fibroblasts in a dose-dependent manner $(\mathrm{P}<0.05)$. Furthermore, $\mathrm{BQZ}$ decreased the expression of $\mathrm{Cbf} \alpha 1$ protein, an osteoblast marker (22), which indicated that BQZ could suppress the osteogenic differentiation of fibroblasts.

In addition, the protein expression levels of $\mathrm{Cx} 43$ and $\mathrm{pCx} 43$ were suppressed by BQZ. These results indicated that BQZ may affect the osteogenic differentiation of fibroblasts by regulating $\mathrm{Cx} 43$. Overproduction of BMP-2 was noted in AS patients (30). BMP-2 is secreted mainly by osteoblasts, and the high levels of BMP-2 is AS patients may lead to new bone formation by stimulating the osteogenic differentiation of fibroblasts (31). Thus, fibroblasts in the present study were stimulated with rhBMP-2 to simulate a physiological state comparable to AS. The results demonstrated that BQZ was able to decrease the level of $\mathrm{Cbf} \alpha 1$ and $\mathrm{Cx} 43 / \mathrm{pCx} 43$ in rat fibroblast cells stimulated with rhBMP-2

The anti-inflammatory chemical celecoxib is a first-line drug option for patients with AS (11). Numerous lines of evidence have indicated that celecoxib may slow radiographic progression in patients with AS, by suppressing fibroblast proliferation and collagen expression $(10,32)$. Notably, BQZ showed similar effects to those of celecoxib regarding the inhibition of $\mathrm{Cbf} \alpha 1$ and $\mathrm{Cx} 43 / \mathrm{pCx} 43$ protein expression. These results may elucidate in part the mechanisms underlying the anti-AS effect of BQZ, and may lead to the discovery of novel drugs adding to the available therapeutic interventions for AS patients.

The study demonstrated that $\mathrm{BQZ}$ is able to decrease the protein levels of $\mathrm{Cx} 43 / \mathrm{pCx} 43$ and $\mathrm{Cbf} \alpha 1$ in fibroblasts in the presence or absence of rhBMP-2. These results indicate that BQZ may exert anti-AS effects via the suppression of the osteogenic differentiation of fibroblasts by regulating Cx43.

Overall, the present results indicate the anti-AS effect of BQZ. Thus, this study may provide an experimental basis for the identification of novel anti-ossification drugs which inhibit fibroblast proliferation and osteogenic differentiation. However, it remains unclear whether selective $\mathrm{Cx} 43$ blockers could inhibit Cbf $\alpha 1$ expression in a similar manner to BQZ. Furthermore, it is not clear which downstream signal transduction pathway(s) of $\mathrm{Cx} 43$ are necessary for the BMP-2/Cbf $\alpha 1$ pathway regulation, and whether BQZ may exhibit similar effects in vivo. We intend to validate the present approach in rat models in further studies.

\section{Acknowledgements}

This study was supported by National Natural Science Foundation of China (grant no. 81273736).

\section{References}

1. Wendling D and Claudepierre P: New bone formation in axial spondyloarthritis. Joint Bone Spine 80: 454-458, 2013.

2. Xiang YJ and Dai SM: Prevalence of rheumatic diseases and disability in China. Rheumatol Int 29: 481-490, 2009.

3. Yu F, Cui Y, Zhou X, Zhang X and Han J: Osteogenic differentiation of human ligament fibroblasts induced by conditioned medium of osteoclast-like cells. Biosci Trends 5: 46-51,2011.

4. Nishimura R, Hata K, Harris SE, Ikeda F and Yoneda T: Core-binding factor alpha 1 (Cbfa1) induces osteoblastic differentiation of $\mathrm{C} 2 \mathrm{C} 12$ cells without interactions with Smad1 and Smad5. Bone 31: 303-312, 2002.

5. Kopf J,Petersen A, Duda GN and Knaus P: BMP2 and mechanical loading cooperatively regulate immediate early signalling events in the BMP pathway. BMC Biol 10: 37, 2012.

6. Zhang $\mathrm{J}$ and Wang JH: BMP-2 mediates PGE(2)-induced reduction of proliferation and osteogenic differentiation of human tendon stem cells. J Orthop Res 30: 47-52, 2012.

7. Chen HA, Chen CH, Lin YJ, Chen PC, Chen WS, Lu CL and Chou CT: Association of bone morphogenetic proteins with spinal fusion in ankylosing spondylitis. J Rheumatol 37: 2126-2132, 2010 .

8. Hashida Y, Nakahama K, Shimizu K, Akiyama M, Harada K and Morita I: Communication-dependent mineralization of osteoblasts via gap junctions. Bone 61: 19-26, 2014. 
9. Yang HS, Lu XH, Chen DY, Yuan W, Yang LL, He HL and Chen Y: Upregulated expression of connexin43 in spinal ligament fibroblasts derived from patients presenting ossification of the posterior longitudinal ligament. Spine (Phila Pa 1976) 36: 2267-2274, 2011

10. Haroon N, Kim TH and Inman RD: NSAIDs and radiographic progression in ankylosing spondylitis Bagging big game with small arms? Ann Rheum Dis 71: 1593-1595, 2012.

11. Braun $J$, van den Berg $R$, Baraliakos $X$, Boehm $H$, Burgos-Vargas R, Collantes-Estevez E, Dagfinrud H, Dijkmans B, Dougados M, Emery P, et al: 2010 update of the ASAS/EULAR recommendations for the management of ankylosing spondylitis. Ann Rheum Dis 70: 896-904, 2011.

12. Kristensen LE, Jakobsen AK, Askling J, Nielsson F and Jacobsson LT: Safety of etoricoxib, celecoxib, and nonselective Nonsteroidal Antiinflammatory Drugs in Ankylosing spondylitis and other Spondyloarthritis patients: A Swedish national population-based cohort study. Arthritis Care Res (Hoboken) 67: $1137-1149,2015$

13. Escalas C, Trijau S and Dougados M: Evaluation of the treatment effect of NSAIDs/TNF blockers according to different domains in ankylosing spondylitis: Results of a meta-analysis Rheumatology (Oxford) 49: 1317-1325, 2010.

14. Baraliakos X, Haibel H, Listing J, Sieper J and Braun J: Continuous long-term anti-TNF therapy does not lead to an increase in the rate of new bone formation over 8 years in patients with ankylosing spondylitis. Ann Rheum Dis 73 710-715, 2014.

15. Zhang N, Zhang YZ, Tao QW and Yan XP: Treatment of ankylosing spondylitis by modified bushen zhuanggu recipe: A clinical observation. Zhongguo Zhong Xi Yi Jie He Za Zhi 33: 1611-1616, 2013 (In Chinese).

16. Huang RY, Lin JH, He XH, Li X, Lu CL, Zhou YY, Cai J and He YT: Anti-inflammatory activity of extracts of Bushen-Qiangdu-Zhilv decoction, a Chinese medicinal formula, in M1-polarized RAW264.7. BMC Complement Altern Med 14: 268, 2014.

17. Garber JC BRBJ: Guide for the care and use of laboratory animals. United State: National Academies Press, 2011.

18. Men T, Piao SH and Teng CB: Regulation of differentiation of mesenchymal stem cells by the Hippo pathway effectors TAZ/YAP. Yi Chuan 35: 1283-1290, 2013 (In Chinese).

19. Zouani OF, Rami L, Lei Y and Durrieu MC: Insights into the osteoblast precursor differentiation towards mature osteoblasts induced by continuous BMP-2 signaling. Biol Open 2: 872-881, 2013.

20. Umehara K, Iimura T, Sakamoto K, Lin Z, Kasugai S, Igarashi $\mathrm{Y}$ and Yamaguchi A: Canine oral mucosal fibroblasts differentiate into osteoblastic cells in response to BMP-2. Anat Rec (Hoboken) 295: 1327-1335, 2012.
21. Rutherford RB, Moalli M, Franceschi RT, Wang D, Gu K and Krebsbach PH: Bone morphogenetic protein-transduced human fibroblasts convert to osteoblasts and form bone in vivo. Tissue Eng 8: 441-452, 2002.

22. Ducy P, Schinke T and Karsenty G: The osteoblast: A sophisticated fibroblast under central surveillance. Science 289: 1501-1504, 2000

23. Harada H, Tagashira S, Fujiwara M, Ogawa S, Katsumata T, Yamaguchi A, Komori T and Nakatsuka M: Cbfa1 isoforms exert functional differences in osteoblast differentiation. J Biol Chem 274: 6972-6978, 1999.

24. Banerjee C, Hiebert SW, Stein JL, Lian JB and Stein GS: An AML-1 consensus sequence binds an osteoblast-specific complex and transcriptionally activates the osteocalcin gene. Proc Natl Acad Sci USA 93: 4968-4973, 1996.

25. Kern B, Shen J, Starbuck M and Karsenty G: Cbfa1 contributes to the osteoblast-specific expression of type I collagen genes. J Biol Chem 276: 7101-7107, 2001

26. Lee MH, Javed A, Kim HJ, Shin HI, Gutierrez S, Choi JY, Rosen V, Stein JL, van Wijnen AJ, Stein GS, et al: Transient upregulation of CBFA1 in response to bone morphogenetic protein-2 and transforming growth factor beta1 in $\mathrm{C} 2 \mathrm{C} 12$ myogenic cells coincides with suppression of the myogenic phenotype but is not sufficient for osteoblast differentiation. J Cell Biochem 73: 114-125, 1999.

27. Loiselle AE, Paul EM, Lewis GS and Donahue HJ: Osteoblast and osteocyte-specific loss of Connexin43 results in delayed bone formation and healing during murine fracture healing. J Orthop Res 31: 147-154, 2013

28. Li S, Zhang H, Li S, Yang Y, Huo B and Zhang D: Connexin43 and ERK regulate tension-induced signal transduction in human periodontal ligament fibroblasts. J Orthop Res 33: 1008-1014, 2015.

29. Niger C, Lima F, Yoo DJ, Gupta RR, Buo AM, Hebert C and Stains JP: The transcriptional activity of osterix requires the recruitment of $\mathrm{Sp} 1$ to the osteocalcin proximal promoter. Bone 49: 683-692, 2011.

30. Park MC, Park YB and Lee SK: Relationship of bone morphogenetic proteins to disease activity and radiographic damage in patients with ankylosing spondylitis. Scand J Rheumatol 37: 200-204, 2008.

31. Chen MH, Chen HA, Chen WS, Chen MH, Tsai CY and Chou CT: Upregulation of BMP-2 expression in peripheral blood mononuclear cells by proinflammatory cytokines and radiographic progression in ankylosing spondylitis. Mod Rheumatol 25: 913-918, 2015.

32. Li F, Fan C, Zeng B, Zhang C, Chai Y, Liu S and Ouyang Y: Celecoxib suppresses fibroblast proliferation and collagen expression by inhibiting ERK1/2 and SMAD2/3 phosphorylation. Mol Med Rep 5: 827-831, 2012. 